\title{
Identifikasi Isolat Klinik Methicillin-resistant Staphylococcus aureus dan Extended-Spectrum Beta-Lactamase Menggunakan Teknik Polimerase Chain Reaction
}

\author{
Linosefa, Netti Suharti, Andani Eka Putra
}

\begin{abstract}
Abstrak
Bakteri patogen yang resisten terhadap banyak obat seperti Staphylococcus aureus yang kebal terhadap Methicillin (Methicillin-resistant Staphylococcus aureus/MRSA) telah menjadi agen penyebab infeksi baik di lingkungan pelayanan kesehatan maupun di masyarakat. Extended-Spectrum Beta-Lactamase (ESBL) yang berasal dari mutasi $\beta$-laktamase juga menjadi masalah utama dalam infeksi terkait pelayanan kesehatan. Tujuan: Menentukan proporsi bakteri penghasil MRSA dan ESBL dari isolat klinis di Rumah Sakit Dr. M. Djamil Padang menggunakan teknik Polimerase Chain Reaction (PCR). Metode: Penelitian ini merupakan studi prospektif dengan mengumpulkan isolat Staphylococcus aureus dan Enterobacteriaceae dari Juli hingga September 2017. Penelitian dilakukan di Fakultas Kedokteran Universitas Andalas untuk mengkonfirmasi bakteri penghasil MRSA dan ESBL. Hasil: Sebanyak 15 dari 27 isolat Staphylococcus aureus (56\%) merupakan MRSA dan 21 dari 41 isolat Enterobacteriaceae (51\%) adalah penghasil ESBL. Klebsiella sp. paling banyak ditemukan di antara isolat Enterobacteriaceae (59\%). Lima puluh persen Klebsiella sp menghasilkan ESBL. Simpulan: Studi ini menunjukkan bahwa setengah isolat klinis dari RSUP Dr. M. Djamil merupakan MRSA dan penghasil ESBL. Deteksi dini MRSA dan Enterobacteriaceae penghasil ESBL perlu dilakukan, untuk mencegah dan mengurangi transmisi bakteri MDR di lingkungan rumah sakit.
\end{abstract}

Kata kunci: Enterobacteriaceae, Klebsiella sp, MDR, Staphylococcus aureus

\begin{abstract}
Multidrug resistance (MDR) pathogen such as Methicillin-Resistant Staphylococcus Aureus (MRSA) has become an increasingly causative agent of infection in both healthcare and community settings. Extended-Spectrum BetaLactamase (ESBL) which derived from mutated $\beta$-lactamase also become a major problem in healthcare-associated infection. Objectives: To determined the proportion of MRSA and ESBL from the clinical isolate from Dr. M. Djamil Hospital Padang. Methods: It was a prospective study by collected Staphylococcus aureus and Enterobacteriaceae isolate from July to September 2017. The Polymerase Chain Reaction (PCR) was performed in The Faculty of Medicine of Universitas Andalas to confirm the MRSA and ESBL. Results: A total of 15 from 27 Staphylococcus aureus isolate (56\%) were MRSA positive and 21 of 41 Enterobacteriaceae isolate (51\%) were ESBL positive. Klebsiella sp. were dominant among the Enterobacteriaceae (59\%) isolate. Fifty percent of Klebsiella sp were ESBL producer. Simpulan: This study shows that almost a half of clinical isolate from RSUP Dr. M. Djamil were MRSA and ESBL producer. Early detection for MRSA and ESBL need to perform in a clinical setting, in order to prevent and reduce the transmission of MDR pathogen.
\end{abstract}

Keywords: Enterobacteriaceae, Klebsiella sp, MDR, Staphylococcus aureus

Affiliasi penulis: Bagian Mikrobiologi, Fakultas Kedokteran, Universitas Andalas, Padang

Korespondensi: Linosefa, Email: linosefa@med.unand.ac.id

Telp: +6281374449708

\section{PENDAHULUAN}

Infeksi yang disebabkan oleh bakteri Multidrug Resistance (MDR), saat ini semakin meningkat jumlahnya. Hal ini menyebabkan pengobatan antibiotik 
menjadi terbatas dan mortalitas lebih tinggi untuk pasien rawat inap. Bakteri MDR yang sering ditemukan sebagai penyebab infeksi di lingkungan rumah sakit adalah Methicillin-Resistant Staphylococcus aureus (MRSA) dan bakteri penghasil Extended-Spectrum Beta-Lactamase (ESBL). ESBL dihasilkan umumnya oleh Enterobacteriaceae. Insiden infeksi MRSA adalah sekitar 2,3-69,1\% (Hassoun, Linden et al. 2017) dan 7-15\% untuk infeksi ESBL. ${ }^{1,2}$

Sifat resisten terhadap metisilin pada MRSA terutama disebabkan oleh PBP2a/PBP2 yang diproduksi oleh gen mecA.3,4 B-strain bakteri yang memiliki PBP2a, juga menjadi resisten terhadap antibiotik $\beta$-laktam lain termasuk penisilin, sefalosporin, $\beta$-laktamase inhibitor, monobaktam dan Carbapenem. $^{5}$

Enterobacteriaceae penghasil ESBL, selain mengakibatkan bakteri resisten terhadap sefalosporin, juga umumnya menjadi resisten terhadap fluoroquinolone. Ada banyak gen yang bertanggung jawab untuk memproduksi ESBL, salah satunya adalah gen SHV. ${ }^{6,7}$ Pasien yang dirawat di rumah sakit dengan penyakit berat, rawatan yang lama, terpasang peralatan invasif dan penggunaan antibiotik secara berlebihan memiliki risiko lebih tinggi untuk terinfeksi oleh bakteri ini. Penelitian ini bertujuan untuk mengidentifikasi karakteristik resistensi dari bakteri penghasil MRSA dan ESBL secara genotip, untuk mengeksplorasi data epidemiologis dan untuk membantu penggunaan terapi antibiotik secara tepat.

\section{METODE}

Penelitian deskriptif eksperimental prospektif ini dilakukan di Rumah Sakit Dr. M. Djamil Padang dan Pusat Diagnostik dan Riset Bagian Mikrobiologi Fakultas Kedokteran Universitas Andalas Padang (FK Unand). Penelitian ini telah disetujui oleh Komite Etika Medis Fakultas Kedokteran Universitas Andalas (No. 265/KEP/FK/2017).

-Populasi penelitian

Semua isolat Staphylococcus aureus dan Enterobacteriaceae yang diisolasi dari sampel klinis Rumah Sakit Dr. M. Djamil Padang dari Juli hingga September 2017 dimasukkan dalam penelitian ini.
-Isolat Bakteri

Semua isolat kemudian disimpan dalam TSB gliserol $10 \%$ sebelum disubkultur ke Mac Conkey dan pelat agar darah. Inkubasi dilakukan pada $35^{\circ} \mathrm{C}$ selama 18-24 jam.

\section{-Ekstraksi DNA}

Ekstraksi DNA dilakukan dengan menggunakan teknik pemanasan. Koloni bakteri disuspensikan ke dalam $1 \mathrm{ml}$ PBS dan disentrifugasi pada 12.000 rpm selama 5 menit. Pelet diresuspensi ke dalam $1 \mathrm{ml} \mathrm{TE}$ dan dipanaskan pada $95^{\circ} \mathrm{C}$ selama 10 menit. Setelah sentrifugasi pada $12.000 \mathrm{rpm}$ selama 5 menit, supernatan digunakan sebagai template PCR.

-Amplifikasi PCR

PCR dilakukan untuk mendeteksi gen mecA untuk MRSA dan gen SVH untuk produsen ESBL. Primer yang digunakan untuk mecA adalah MECA P4 5' TCCAGATTACAACTTCACCAGG 3' dan MECA P7 5' CCACTTCATATCTTGTAACG 3'. ${ }^{8}$ Hasil ekstraksi DNA $(1.5 \mu \mathrm{l})$ ditambahkan ke 22,5 $\mu \mathrm{l}$ campuran PCR dan $10 \mu \mathrm{mol}$ primer. Kondisi thermocycling diatur pada $95^{\circ} \mathrm{C}$ selama 10 menit; diikuti oleh 35 siklus $95^{\circ} \mathrm{C}$ selama 30 detik, $55^{\circ} \mathrm{C}$ selama 30 detik, $72^{\circ} \mathrm{C}$ selama 1 menit, dan $70^{\circ} \mathrm{C}$ selama 5 menit. Amplikon divisualisasikan menggunakan elektroforesis dalam gel agarosa 2\% (ukuran 162 bp untuk mecA).

Primer yang digunakan untuk SVH adalah SHVF 5' GATGAACGCTTTCCCATGATG'3 dan SHVR 5'CGCTGTTATCGCTCATGGTAA '3. ${ }^{9}$ Hasil ekstraksi DNA $(1,5 \mu \mathrm{l})$ ditambahkan ke $22,5 \mu \mathrm{l}$ campuran PCR dan $0,5 \mu \mathrm{l}$ masing-masing primer. Kondisi thermocycling diatur pada $95^{\circ} \mathrm{C}$ selama 5 menit; diikuti oleh 35 siklus $95^{\circ} \mathrm{C}$ selama 30 detik, $58^{\circ} \mathrm{C}$ selama 30 detik, $72^{\circ} \mathrm{C}$ selama 30 detik, dan $70^{\circ} \mathrm{C}$ selama 10 menit. Amplikon divisualisasikan menggunakan elektroforesis dalam gel agarosa 2\% (ukuran 214 bp untuk SVH).

\section{HASIL}

Enam puluh delapan isolat yang dimasukkan dalam penelitian ini terdiri dari Staphylococcus aureus 27 isolat dan 41 isolat Enterobacteriaceae (isolat 
Proteus spp 5, isolat Escherichia coli 12, dan isolat Klebsiella sp 24).

Gambar elektroforesis gel agarosa setelah amplifikasi PCR untuk Staphylococcus aureus dan Enterobacteriaceae ditunjukkan pada Gambar 1 dan 2

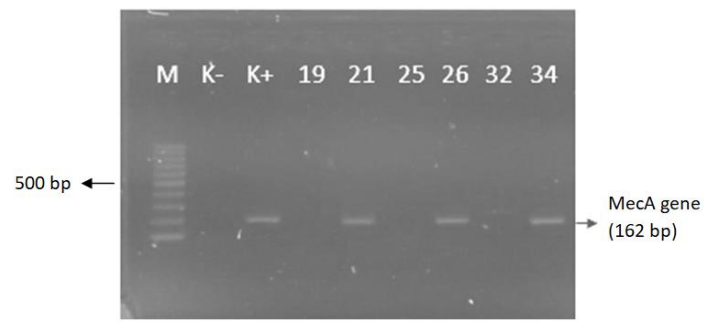

Gambar 1. Gambar elektroforesis gel agarosa setelah gen mecA amplifikasi (162 bp) dengan metode PCR. (untuk isolat no 19, 21, 25, 26, 32 dan 34)

Gambar 1 menunjukkan bahwa isolat nomor 19 dan 25 tidak memiliki amplikon pita mecA. Lima puluh enam persen isolat Staphylococcus aureus memiliki gen mecA.

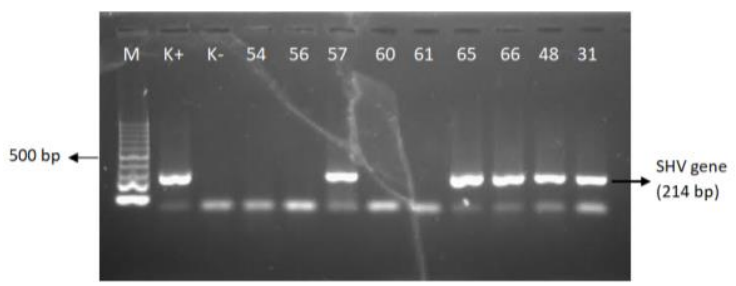

Gambar 2. Gambar elektroforesis gel agarosa setelah amplifikasi gen SHV (214 bp) dengan metode PCR (untuk isolat no $31,48,54,56,57,60,61,65$ dan 66)

Gambar 2 menunjukkan bahwa isolat nomor 54, 56, 60 dan 61 tidak memiliki pita SHV. Hasil SHV dirangkum dalam Tabel 1.

Tabel 1. Hasil PCR Enterobacteriaceae untuk SHV.

\begin{tabular}{ccc}
\hline Isolat & N (\%) & SHV positif (\%) \\
\hline Proteus sp. & $5(12)$ & $2(40)$ \\
Eschericia coli & $12(29)$ & $7(58)$ \\
Klebsiella sp. & $24(59)$ & $12(50)$ \\
\hline Total & 41 & $21(51)$
\end{tabular}

\section{PEMBAHASAN}

MRSA dikenal sebagai salah satu patogen yang sering menyebabkan infeksi terkait pelayanan kesehatan dan komunitas. Metode PCR adalah metode standar emas untuk mengidentifikasi MRSA. Prevalensi MRSA (56\%) yang ditemukan dalam penelitian ini lebih tinggi daripada penelitian lain $(45,1 \%),{ }^{10}$ tetapi lebih rendah dari studi di Teheran (69\%). ${ }^{11}$ Penggunaan alat diagnostik cepat dan teknik yang akurat untuk identifikasi MRSA dapat berkontribusi untuk diagnosis dini dan pengobatan infeksi.

Isolat Enterobacteriaceae dalam penelitian ini yang menyebabkan infeksi, secara genotip separuhnya menghasilkan ESBL (51\%). Hasil ini lebih tinggi dari penelitian lain di Syiria yang ditemukan ESBL dari gen SHV sekitar 12,5\%, ${ }^{13}$ Tetapi penelitian lain di Brazil menemukan tingkat ESBL lebih tinggi $(67,8 \%) .{ }^{12}$ Hasil negatif tidak menghilangkan kemungkinan bakteri memproduksi ESBL karena ada gen lain yang dapat menghasilkan ESBL seperti TEM, CTX-M, OXA. Gen ini tidak diuji dalam penelitian ini. Prevalensi bakteri penghasil ESBL yang paling banyak adalah Klebsiella sp (51\%). Klebsiella sp lebih sering ditemukan sebagai penyebab infeksi bakteri daripada Enterobacteriaceae lainnya. Salah satu ciri khas Klebsiella $s p$ dan E. coli adalah lebih tahan terhadap banyak kelompok antibiotik. Karakteristik resistensi ini dibawa oleh plasmid yang mudah ditransfer, sehingga ESBL lebih sering ditemukan pada Klebsiella sp dan E. coli. ${ }^{6,7}$

Prevalensi ESBL mulai meningkat sebagai akibat dari penggunaan antibiotik yang tidak rasional, yang dapat memicu resistensi antibiotik. Pasien dengan rawatan yang lama dan terpasang peralatan invasif akan meningkatkan risiko kolonisasi bakteri ESBL dan risiko untuk mendapatkan kegagalan terapi. Deteksi dini untuk produsen MRSA dan ESBL perlu dilakukan di lingkungan rumah sakit, untuk mencegah dan mengurangi transmisi patogen MDR.

\section{SIMPULAN}

Peningkatan prevalensi MRSA dan Enterobacteriacea penghasil ESBL, mengakibatkan keduanya harus termasuk dalam deteksi cepat MDRO. Metode PCR adalah metode yang berguna untuk deteksi cepat gen mecA dan SHV dan dapat memberikan manfaat untuk program pengendalian infeksi. 


\section{UCAPAN TERIMA KASIH}

Penelitian ini didanai oleh Universitas andalas pada tahun 2017.

\section{DAFTAR PUSTAKA}

1. Hassoun A, Linden PK, Friedman B. Incidence, prevalence, dan management of MRSA bacteremia across patient populations a review of recent developments in MRSA management dantreatment. Critical Care. 2017;21(211): 1-10.

2. Flokas ME, Karanika S, Alevizakos M, Mylonakis E. Prevalence of ESBL - producing entero bacteriaceae in pediatric bloodstream infections: a systematic review dan meta - analysis. PLoS ONE. 2017;12(1): e0171216.

3. Stapleton PD, Taylor PW. Methicillin resistance in Staphylococcus aureus: mechanisms dan modulation. Sci Prog. 2002;85:57-72.

4. Gilmore KS, Gilmore MS, Sahm DF. Methicillin resistance in Staphylococcus aureus. Bacterial Resistance To Antimicrobials. CRC Press USA. 2008; 292-303.

5. Zapun A, Macheboeuf P, Vernet T. Penicillinbinding proteins danb-lactam resistance. Dalam: Mayers DL, Lerner SA, Ouellette M, Sobel JD. Antimicrobial drug resistance: Mechanisms of drug resistance. Volume-1. New York, Humana Press. 2009.hlm.145-64.

6. Briceno D, Torres J, Tafur J, Quinn J, Villegas M. Antibiotic discovery and development. London: Springer Science+Business Media;2012.hlm.653-9

7. Grover N, Sahni A, Bhattacharya S. Therapeutic challenges of ESBLs danAmpC beta-lactamase producers in a tertiary care center. Med $\mathrm{J}$ Armed Forces India. 2013;69(1):4-10.
8. Zhang K, Sparling J, Chow BL. New quadriplex PCR assay for detection of methicillin and mupirocin resistance and simultaneous discrimination of Staphylococcus aureus from coagulase-negative Staphylococci. Journal of Clinical Microbiology. 2004; 42:4947-55.

9. Kim J, Jeon S, Rhie H, Lee B, Park M, Hoanjong Lee, Jina Lee, Kim S. Rapid detection of extended spectrum $\quad \beta$-lactamase (ESBL) for Enterobacteriaceae by use of a Multiplex PCRbased Method. Infect Chemothe. 2009;41(3):181-4.

10. Pournajaf A, Ardebili A, Goudarzi L, Khodabandeh M, NarimaniT, Abbaszadeh H. PCR-based identification of methicillin-resistant Staphylococcus aureus strains dantheir antibiotic resistance profiles. Asian Pacific Journal of Tropical Biomedicine. 2014;4:S293-S7.

11. Sahebnasagh $R$, Saderi $H$, Owlia $P$. The prevalence of resistance to methicillin in Staphylococcus aureus strains Isolated from patients by PCR method for detection of mecA dannuc Genes. Iranian J Publ Health. 2014; 43(1): 84-92.

12. Oliveira CFD, Salla A, Lara VM, Rieger A, Horta JA, Alves SH. Prevalence of extended-spectrum beta-lactamases-producing microorganisms in nosocomial patients and molecular characterization of the SHV type isolates. Brazilian Journal of Microbiology. 2010;41:278-82.

13. Subol ALI, Youssef N. Prevalence of CTX-M, TEM dan SHV Beta-lactamases in clinical isolates of Escherichia coli and Klebsiella pneumoniae isolated from Aleppo University Hospitals, Aleppo, Syria. Arch Clin Infect Dis. 2015;10(2):e22540. 